Review Article

\title{
Definitions of Frailty in Qualitative Research: A Qualitative Systematic Review
}

\author{
Deborah A. Lekan $\mathbb{D D}^{1}{ }^{1}$ Susan K. Collins, ${ }^{1}$ and Audai A. Hayajneh ${ }^{2}$ \\ ${ }^{1}$ University of North Carolina at Greensboro, School of Nursing, Nursing and Instructional Building, Greensboro, NC 27402, USA \\ ${ }^{2}$ Jordan University of Science and Technology, Faculty of Nursing, Ar Ramtha, Jordan \\ Correspondence should be addressed to Deborah A. Lekan; dalekan@uncg.edu
}

Received 2 July 2020; Accepted 21 May 2021; Published 2 June 2021

Academic Editor: Hélio J. Coelho-Júnior

Copyright (c) 2021 Deborah A. Lekan et al. This is an open access article distributed under the Creative Commons Attribution License, which permits unrestricted use, distribution, and reproduction in any medium, provided the original work is properly cited.

\begin{abstract}
The purpose of this qualitative systematic review was to examine how frailty was conceptually and operationally defined for participant inclusion in qualitative research focused on the lived experience of frailty in community-living frail older adults. Search of six electronic databases, 1994-2019, yielded 25 studies. Data collection involved extracting the definition of frailty from the study aim, background, literature review, methods, and sampling strategy in each research study. Quality appraisal indicated that 13 studies (52\%) demonstrated potential researcher bias based on insufficient information about participant recruitment, sampling, and relationship between the researcher and participant. Content analysis and concept mapping were applied for data synthesis. Although frailty was generally defined as a multidimensional, biopsychosocial construct with loss of resilience and vulnerability to adverse outcomes, most studies defined the study population based on older age and physical impairments derived from subjective assessment by the researcher, a healthcare professional, or a family member. However, 13 studies (52\%) used objective or performance-based quantitative measures to classify participant frailty. There was no consistency across studies in standardized measures or objective assessment of frailty. Synthesis of the findings yielded four themes: Time, Vulnerability, Loss, and Relationships. The predominance of older age and physical limitations as defining characteristics of frailty raises questions about whether participants were frail, since many older adults at advanced age and with physical limitations are not frail. Lack of clear criteria to classify frailty and reliance on subjective assessment introduces the risk for bias, threatens the validity and interpretation of findings, and hinders transferability of findings to other contexts. Clear frailty inclusion and exclusion criteria and a standardized approach in the reporting of how frailty is conceptually and operationally defined in study abstracts and the methodology used is necessary to facilitate dissemination and development of metasynthesis studies that aggregate qualitative research findings that can be used to inform future research and applications in clinical practice to improve healthcare.
\end{abstract}

\section{Introduction}

The rapid growth in the aging population globally in terms of both number and increasing longevity has drawn attention to the needs of older persons, especially those who are frail [1]. Frailty has been characterized as nonresilient or accelerated aging and the cumulative effect of detrimental physiologic changes and failed integrative responses [2]. Although frailty increases with age, it differs from normal aging and represents the cumulative effect of aging processes, morbidity, and psychosocial, behavioral, and environmental factors on health and well-being [3]. Frailty is a clinical condition that has been used to describe a person who is very old and who may appear thin, weak, fragile, and feeble. However, frailty is also recognized as a state of vulnerability that may not be visibly apparent but is associated with reduced resilience and poor response to and recovery from acute illness and other stressors. Although some hold the opinion, "I know it when I see it," it is also acknowledged that not everyone sees the same thing when it comes to frailty [4]. Managing frailty is recognized as an important component in tailoring healthcare for frail older adults. 
1.1. Literature Review. A growing body of research has contributed new understanding about frailty; however, the views of older adults who are frail may not be included in this scientific work. Despite a proliferation of frailty frameworks and some agreement on aspects of physical frailty, the precise defining characteristics and clinical indicators for frailty and how to measure them in diverse care contexts (e.g., community, nursing home, and acute care hospital) are still evolving [2, 4]. Much of the frailty literature follows a biomedical paradigm focused on pathophysiological etiology, physical function, and phenotypic features of frailty $[2,5]$. Despite a large variety of frameworks on ways to assess frailty, the value of frailty assessment is undisputed because of the serious nature of this condition and its consequences. A previous consensus conference on frailty endorsed the usefulness of defining frailty in clinical settings and the need for a clear conceptual framework, indicating that frailty was a clinical syndrome associated with increased vulnerability and potential for preventing, delaying, or reversing frailty with interventions [5]. There is also recognition that there is no ideal frailty assessment tool; the selection of a tool is based on the population characteristics, available data, clinical context, and purpose of the assessment $[4,6,7]$.

What is frailty and how it should be assessed have not been informed by qualitative literature in meaningful ways that capture the voice of older adults who are frail $[2,8,9]$. The development of quantitative methodologies for assessment of a phenomenon such as frailty is ideally preceded by qualitative research to explore concepts and correlates. The validity of concepts used in quantitative research can be strengthened by being grounded in real-life experiences and verified in first person encounters through interviews and focus groups derived from qualitative research $[10,11]$. Current operational definitions of frailty in the empirical literature typically focus on physical aspects of frailty and overlook psychosocial aspects and other factors that may be more meaningful to frail older adults $[5,8]$.

An understanding of how frailty is defined in qualitative research studies could inform the dialogue and development of frailty assessment frameworks that can be applied in research investigations and in clinical practice. Qualitative research provides insights that are difficult to produce with quantitative measures by providing detailed descriptions of phenomenon of concern such as frailty in real-life contexts. Synthesized qualitative research findings in the format of a metasynthesis provide new knowledge about a topic with greater influence compared to singular studies. An initial scan of the qualitative research literature on the lived experience of frailty in community-living frail, older adults yielded a very small number of articles and no metasynthesis studies. Following screening of a set of articles, we noted that many lacked a clear conceptual and operational definition of frailty, and inclusion criteria for sample selection were ambiguous and often based on older age or the presence of physical impairments.

By design, qualitative research can be less structured and more open-ended and flexible compared to quantitative research; indeed, a recent systematic review of definitions of qualitative research found that there is no consensus about specific qualitative methods or data analysis guidelines [12]. Considering this and the insights from our initial scan of the literature raised concerns about potential methodological issues related to researcher perspectives about frailty that may contribute to bias in ways that would impact the validity, interpretation, and transferability of study findings. Methodological deficits would also prevent inclusion of many articles in qualitative metasynthesis studies. The purpose of this qualitative systematic review was to perform an in-depth analysis of conceptual and operational definitions of frailty applied in participant sampling and inclusion criteria in qualitative research studies that focused on the lived experience of frailty in community-living, frail older adults.

\section{Method}

2.1. Study Design. This study used a qualitative systematic review $[13,14]$. This review uses a process which summarizes primary qualitative research studies on a topic derived from a systematic and rigorous literature search [13]. The research evidence is integrated, compared, and synthesized into a holistic interpretation informed by existing theory and research to more fully comprehend the multiple levels of understanding around a topic $[11,14]$. Methods for systematic reviews of quantitative research are well established; however, the first publication of a systematic review of qualitative research was not until 2013 [13]. The qualitative systematic review could be an important contribution to the science of frailty since the findings can serve as a foundation to develop new insights and propose strategies for future knowledge development [15]. Sandelowski and Barroso's [10] methodology was employed to synthesize primary qualitative research study findings into a holistic interpretation about the researchers' definitions of frailty that was used for participant inclusion criteria in qualitative research on the lived experience of frailty among frail older adults living in the community.

2.2. Literature Search Strategy. A systematic search of six databases was conducted: Cumulative Index to Nursing and Allied Health Literature (CINAHL), MEDLINE (PubMed), ProQuest, PsycINFO, Scopus, and Sociological Abstracts, from their inception through June 2019. The appropriate medical subject headings (MeSH), search terms, and keywords for each database were applied and included the following: "frail elderly" and "qualitative research" (PubMed); "frail" and "middle aged 45-64 years," "aged 65+ years," "aged, 80 and over" (CINAHL); "health impairment," "aging," "middle age (40-64 years)," "aged (65 years \& older)," "very old (85 years \& older)," "qualitative" (PsycINFO); and "aging," "elder," "frail," "gerontology," "geriatric," "senior," and "qualitative methods" (Sociological Abstracts). The search was limited to human subjects and English language. Additional citations were located through hand search of reference lists. Citations were excluded if there was no evidence of the older adult's perspective on frailty. Unpublished papers (e.g., abstracts, dissertations, and 


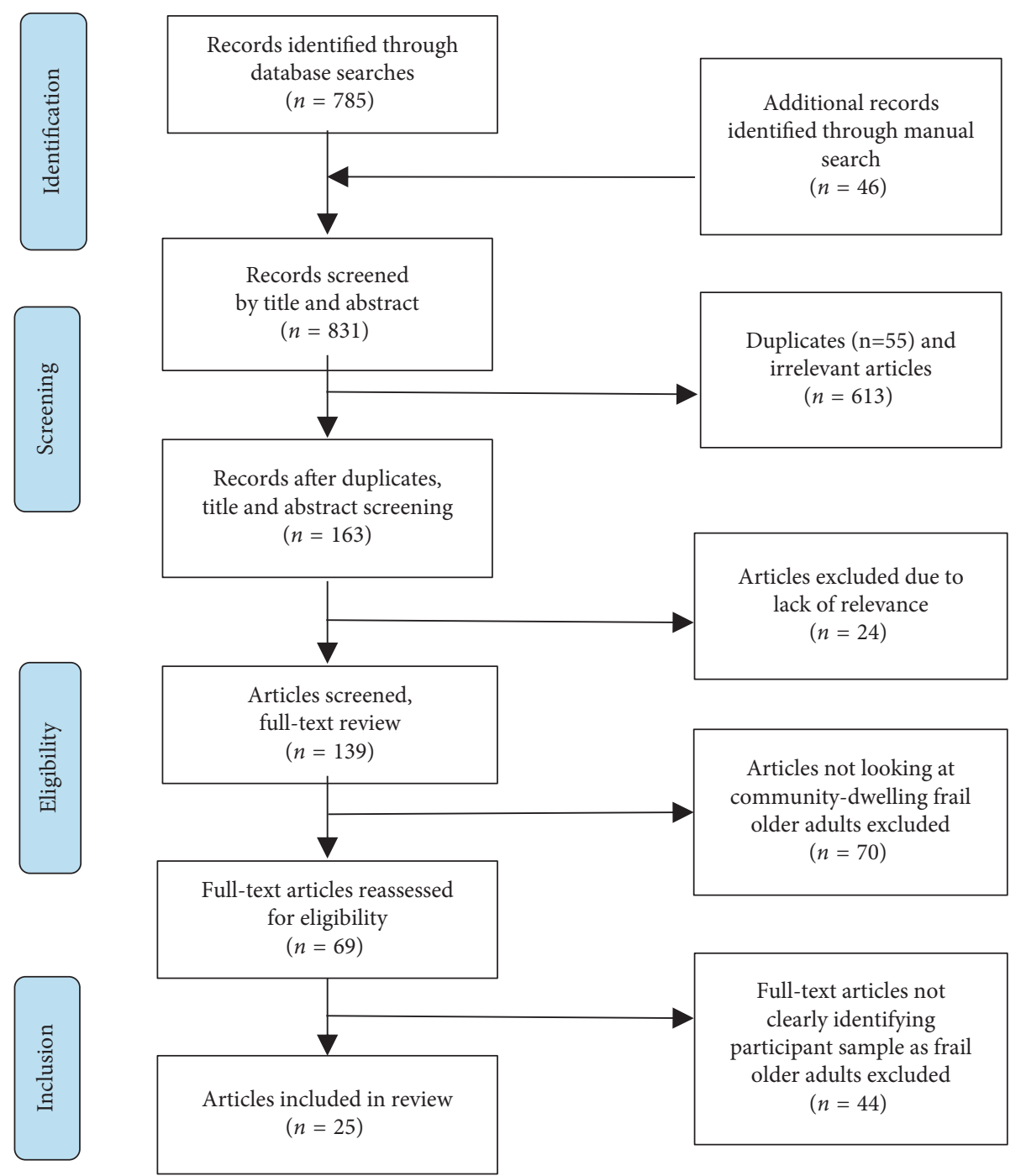

FIGURE 1: Search strategy flow diagram.

conference proceedings) were excluded. Study populations that focused on older adults in acute care hospitals or longterm care settings (e.g., assisted living, nursing homes, and rehabilitation facilities) were excluded since the experience of frailty in these contexts would be different. Studies that addressed end-of-life, advance directives, and failure-tothrive were excluded because these issues are associated with the latest stages of frailty and not the focus of this review.

The search yielded 784 citations; an additional 46 articles were identified manually from author searches and reference lists. Two reviewers independently screened titles and abstracts and rated each citation as meeting screening criteria. Full-text reviews of 138 articles were conducted with exclusion of 70 articles that were not focused on communitydwelling frail older adults. A total of 69 articles underwent a second round of full-text review, with exclusions applied due to the study sample not clearly identified as frail, and 44 were excluded. The final sample included 25 articles. Fourteen of these articles were authored by seven researcher groups (two different studies for each group) in which different research questions were examined in the same participant sample [16-29]. The search strategy is shown in Figure 1.

2.3. Data Abstraction. A first review of the article was conducted by one coauthor. Articles were read in detail with a focus on the study aim or purpose, background and literature review, and methods. Data abstraction included the following: authors, year of publication, first author professional discipline, country of origin of the research, study aim, conceptual and operational definition of frailty, participant recruitment and characteristics, study setting, and ethical considerations. Statements used to define frailty were extracted and entered verbatim into individual data forms. The conceptual definition of frailty referred to how the term frailty was used by the researcher to describe the construct and guide the sample selection. The operational definition of frailty identified how frailty was measured and classified for inclusion in the study. Specific attention was directed to the methods section (e.g., recruitment, sampling, and inclusion and exclusion criteria) of the article. When an explicit 
definition of frailty could not be determined, descriptive terminology for frailty was identified. Care was taken not to confound the researcher's definition of frailty for the purpose of the study with the study findings and interpretation. Frailty statements and terminology were transferred into a Microsoft Excel ${ }^{\odot}$ spreadsheet to facilitate grouping into topical areas. A second review of the article was performed by another coauthor to verify the data abstraction in the data forms and the spreadsheet, making any additions or corrections needed.

2.4. Quality Appraisal. Each article underwent quality appraisal with a focus on the research question, methods, and ethics using the Critical Appraisal Skills Programme (CASP) Qualitative Studies Checklist [30]. There are varying opinions about how quality should be assessed, who should assess quality, and whether quality should be assessed in qualitative research at all given the nature of this research genre [31]. It is also proposed that qualitative research is not generalizable and is specific to a certain context and participant group [31]. In accordance with these and other opinions, we did not exclude any articles based on quality [10], especially since this review was prompted by methodological concerns about how researchers classified participants as frail for qualitative studies on the lived experience of frailty. This qualitative systematic review was undertaken to provide a synthesis of articles that met our inclusion criteria because of its potential to inform the design of future qualitative research on frailty.

\subsection{Data Analysis: Content Analysis and Concept Mapping.} Content analysis [32] was undertaken to identify insights and concepts from statements extracted from each article and coded in the spreadsheets. Coding is the process in which data are reduced into manageable units and categorized for meaningful use. Concept mapping was employed to facilitate reflection and understanding about frailty and to graphically organize and represent key concepts in the data aggregation and reduction process [33]. Concept maps are graphical tools for organizing and representing concepts to facilitate identification of similarities, differences, and patterns in the data [33]. Colored-coded sticky notes with concepts/statements for the conceptual and operational definitions of frailty from the spreadsheet were clustered on a white board for the initial graphical organization of the concepts; this visual display was then replicated in a Microsoft PowerPoint ${ }^{\odot}$ format.

For the synthesis, the color-coded concept groupings were compared, contrasted, and organized into categories. Finally, by collapsing and expanding categories, topical areas emerged, and themes were formed. An iterative process of analysis of concepts produced further refinements leading to classification of data into categories and themes. To ensure validity, the articles were re-reviewed to ensure accurate representation of the concepts, categories, and themes. Regular meetings among our team fostered discussion and interrogation of the data and development of consensus on the categories and themes. The concept map, date-stamped spreadsheets, and meeting notes were maintained for an audit trail and revisited as needed to follow decision-making.

\section{Results}

3.1. Systematic Review Findings. The 25 articles in Table 1 represented various disciplines including nursing (11), medicine and neuroscience (3), sociology and social work (6), occupational therapy (2), dentistry (2), and radiology (1). There was a diverse representation by country of origin, with the majority of articles originating from the United States (10) and the Netherlands (5), followed by Sweden (4), United Kingdom/England (3), Canada (2), Denmark (1), and Taiwan (1). Twenty articles provided a clear conceptual and/or operational definition of frailty, of which 13 articles (52\%) included quantitative objective or performance-based measures for frailty. Frailty definitions were sometimes difficult to locate and were embedded in the background or literature review; articulation of participant inclusion/exclusion criteria in the methods was sometimes unclear. Critical appraisal of the articles using CASP checklist identified 13 studies (52\%) at risk for researcher bias due to insufficient information about participant recruitment; relationship between the researcher and the participant; reliance on subjective judgment of the researcher, a healthcare professional, or a family member to classify or identify frail participants; and lack of clear operational criteria for frailty (see Table 2, questions 4 and 5).

3.2. Older Age and Physical Impairment. Researchers cited older age and physical impairments as the primary frailty markers in the articles in this review. While all articles cited 65 years of age and older as the age cutoff, age greater than 80 years was a primary frailty indicator in nine articles (36\%) $[16,17,22,23,35,38,41]$. In eight articles, frailty was subjectively determined by the researcher or a proxy such as a health professional or family member $[18,19,22,23,35,38,39,41]$. For example, Becker [32] described frailty as the presence of chronic physical impairments in older individuals that the health professional would view as putting them at risk. Nicholson and colleagues $[22,23]$ determined frailty based on recommendations from an interdisciplinary care team that considered old age, inability to carry out activities of daily living, dependence, and vulnerability to physical decline. In several articles, dependence on caregivers and the healthcare system was a frailty indicator $[16,17,19,36,41,44]$. A majority of articles in this review cited impairments in activities of daily living as inclusion criteria for frailty. However, most did not include information about assessment parameters and how measures for physical function were administered (self-reported or provider-administered) or scored [20, 21, 26, 27].

\subsection{Operational Definition for Frailty and Objective Measures.} About half of the articles employed objective or performance-based measures to characterize frailty in the participant sample $(n=13,56 \%)$ (see Table 3$)$. Four articles used validated screening tools for frailty such as grip strength, 
TABLE 1: Description of the qualitative research articles in the study sample $(N=25)$.

\begin{tabular}{|c|c|c|c|}
\hline & $\begin{array}{c}\text { First author, date; } \\
1^{\text {st }} \text { author } \\
\text { discipline; country } \\
\text { of origin; [ID] }\end{array}$ & Aim/purpose & $\begin{array}{l}\text { Conceptual description or } \\
\text { definition of frailty }\end{array}$ \\
\hline 1 & $\begin{array}{c}\text { Andreasen et al., } \\
\text { 2015; occupational } \\
\text { therapy; Denmark; } \\
\text { [34] }\end{array}$ & $\begin{array}{l}\text { To validate the Tilburg } \\
\text { Frailty Indicator on content } \\
\text { by exploring the experience } \\
\text { of daily life of community- } \\
\text { dwelling frail elderly shortly } \\
\text { after discharge from an } \\
\text { acute admission, in relation } \\
\text { to the physical, } \\
\text { psychological, and social } \\
\text { domains of the TFI. }\end{array}$ & $\begin{array}{l}\text { A dynamic state affecting an } \\
\text { individual who experiences } \\
\text { losses in one or more domains } \\
\text { of human functioning } \\
\text { (physical, psychological, } \\
\text { social) that are caused by the } \\
\text { influence of a range of } \\
\text { variables, which increases the } \\
\text { risk of adverse outcomes and } \\
\text { negatively impacts well-being. }\end{array}$ \\
\hline 2 & $\begin{array}{l}\text { Becker, 1994; } \\
\text { social science; } \\
\text { USA; [35] }\end{array}$ & $\begin{array}{l}\text { To explore the meanings } \\
\text { older persons attach to } \\
\text { autonomy and decreases in } \\
\text { physical abilities associated } \\
\text { with frailty. }\end{array}$ & $\begin{array}{c}\text { Chronically dependent older } \\
\text { people, those who are living } \\
\text { with a variety of physical and/ } \\
\text { or cognitive impairments and } \\
\text { experiencing functional losses } \\
\text { and decrease in physical ability } \\
\text { that interfere with ability to } \\
\text { maintain autonomy in } \\
\text { everyday life. }\end{array}$ \\
\hline
\end{tabular}

Operational definition of frailty
Sample $N$; age mean (range) in years; gender; race
Tilburg Frailty Indicator, a 15-item self-administered questionnaire: physical domain (8 items), psychological domain $(4$ items), social domain (3 items). Frailty cutoff score accounts for five of the 15 frailty indicators.

80 years of age and older; frailty determined by opinion of health professional including presence of chronic impairments that health professionals would view as

$N=14 ; 80.6$ (69-93);

7 men, 7 women;

Caucasian putting people at risk.
$N=19 ; \geq 80 ; 12$ men, 16 women; Hispanic and Caucasian, 2

African American women

Frail determined by scoring below cutoff scores, on at

least two of the six following domains: $\mathrm{BMI}<23$;

To investigate the concept of Frail older adults cope with
Claassens et al., 3 2014; medicine; Netherlands; [36] healthcare-related perceived multiple and/or chronic health control from the viewpoint conditions that likely require of frail older adults $>65$ years. more extensive forms of healthcare. cognitive function (MMSE

$<24)$; vision and hearing acuity; grip strength

(handheld dynamometers);

physical activity (how often

\& how long they walked, cycled, performed

household activities, played

sports) during 2 past weeks.
To identify how frail

Donlan, 2011; 4 social work; USA; [37] Mexican American elders
socially constructed the meaning of communitybased care they received. 2012; nursing; Sweden; [16] 6 2013; nursing; Sweden; [17] To explore and identify what influences frail older adults' subjective
Ebrahimi et al., To discover and reveal the
Not described; frailty and disability often accompany old Age $\geq 65$ years and having a $N=6$; 77.5 (66-89); age, especially among marginalized immigrant populations.

As people age, their reserve capacity decreases, and the risk of morbidity and frailty increases; a multidimensional geriatric syndrome of disability; vulnerability and reduced capacity.

A biological geriatric syndrome of reductions in physiological reserve capacity mechanisms against stress and multimorbidity and dependence on others. with one or more chronic

depended on help in at least $N=22 ; 79.5$ (67-92); by a count. experiences of good health. disease which implies a risk of
$N=32 ; 80.5(65-96)$;

13 men, 19 women;

Caucasian

\section{disability. Requiring 3 men, 3 women; assistance with ADLs. Hispanic}

Age $\geq 80$ years or $\geq 65$ years

with one or more chronic

diseases; those who

$N=22 ; 79.5$ (67-92);

depended on help in at least 11 men, 11 women; one ADL and sought Caucasian

emergency treatment in a hospital.

Age $\geq 80$ years or $\geq 65$ years diseases; those who one ADL and sought

emergency treatment in a

11 men, 10 women;

Caucasian 
TABle 1: Continued.

\begin{tabular}{|c|c|c|c|c|c|}
\hline & $\begin{array}{l}\text { First author, date; } \\
1^{\text {st }} \text { author } \\
\text { discipline; country } \\
\text { of origin; [ID] }\end{array}$ & Aim/purpose & $\begin{array}{c}\text { Conceptual description or } \\
\text { definition of frailty }\end{array}$ & $\begin{array}{l}\text { Operational definition of } \\
\text { frailty }\end{array}$ & $\begin{array}{c}\text { Sample } N \text {; age mean } \\
\text { (range) in years; } \\
\text { gender; race }\end{array}$ \\
\hline 7 & $\begin{array}{c}\text { Ekelund et al., } \\
\text { 2014; occupational } \\
\text { therapy; Sweden; } \\
\text { [38] }\end{array}$ & $\begin{array}{l}\text { To explore community- } \\
\text { living frail older persons' } \\
\text { conceptions of self- } \\
\text { determination. }\end{array}$ & $\begin{array}{l}\text { A physiological state of } \\
\text { increased vulnerability to } \\
\text { stressors that result from } \\
\text { decreased physiological } \\
\text { reserve; related to risk for } \\
\text { disability and comorbidity; the } \\
\text { presence of various diseases, } \\
\text { age discrimination, and } \\
\text { paternalism impact frailty; } \\
\text { dependency is an important } \\
\text { aspect of frailty. }\end{array}$ & $\begin{array}{c}\text { Age } \geq 80 \text { years or } \geq 65 \text { years } \\
\text { with one or more chronic } \\
\text { diseases; those who } \\
\text { depended on help in at least } \\
\text { one ADL and sought } \\
\text { emergency treatment in a } \\
\text { hospital. }\end{array}$ & $\begin{array}{c}N=15 ; 80.5(68-92) ; \\
8 \text { men, } 7 \text { women; } \\
\text { Caucasian }\end{array}$ \\
\hline 8 & $\begin{array}{c}\text { Evans et al., 2001; } \\
\text { radiology; USA; } \\
\text { [39] }\end{array}$ & $\begin{array}{l}\text { To investigate whether frail } \\
\text { older women with a positive } \\
\text { perception of health would } \\
\text { desire to take a more active } \\
\text { role in their healthcare. }\end{array}$ & $\begin{array}{l}\text { Frail older adults are defined } \\
\text { as those individuals who suffer } \\
\text { major physical, mental, or } \\
\text { social losses and require a } \\
\text { range of supportive and } \\
\text { restorative services. }\end{array}$ & $\begin{array}{l}\text { Frailty criteria/measures not } \\
\text { clearly specified, but older } \\
\text { women were } \\
\text { “. . .categorized by age as } \\
\text { frail older adults." } \\
\text { Convenience sample of frail } \\
\text { older women who were } \\
\text { scheduled for ultrasound } \\
\text { examination and whose } \\
\text { health status indicates } \\
\text { ability to participate in } \\
\text { interviews. }\end{array}$ & $\begin{array}{c}N=4 ; 82.25(76-90) ; \\
4 \text { women; not } \\
\text { reported }\end{array}$ \\
\hline 9 & $\begin{array}{l}\text { Grenier \& Hanley, } \\
\text { 2007; social work; } \\
\text { Canada; [19] }\end{array}$ & $\begin{array}{l}\text { To explore the life } \\
\text { experiences of frailty. }\end{array}$ & $\begin{array}{l}\text { Definition derived from the } \\
\text { social label of frailty and not } \\
\text { physical function and was } \\
\text { related to the presence of } \\
\text { comorbidities. The social } \\
\text { context of frailty as the "little } \\
\text { old lady" of small stature, } \\
\text { being fragile and weak, is } \\
\text { associated with assumptions } \\
\text { that shape the gendered } \\
\text { experience of older women. } \\
\text { Frailty framed in context of } \\
\text { resistance to dominant } \\
\text { notions of aging and gender, } \\
\text { to challenge social constructs } \\
\text { and expectations for aging and } \\
\text { frailty. Frailty is also a term } \\
\text { used by health professionals to } \\
\text { assess a person's need for } \\
\text { public services to meet } \\
\text { physical needs. }\end{array}$ & $\begin{array}{l}\text { Frailty criteria/measures not } \\
\text { specified. Frailty } \\
\text { determination is based on } \\
\text { clinical judgment and home } \\
\text { care eligibility by health } \\
\text { professionals for half of the } \\
\text { sample, and the other half } \\
\text { were active in an advocacy } \\
\text { organization but fell outside } \\
\text { the classification because } \\
\text { they did not receive public } \\
\text { services due to lack of } \\
\text { physical need, interest, or } \\
\text { financial resources to pay } \\
\text { privately. }\end{array}$ & $\begin{array}{c}N=12 ;>55 ; 12 \\
\text { women; not } \\
\text { reported }\end{array}$ \\
\hline
\end{tabular}


TABle 1: Continued.

\begin{tabular}{|c|c|c|c|c|c|}
\hline & $\begin{array}{l}\text { First author, date; } \\
1^{\text {st }} \text { author } \\
\text { discipline; country } \\
\text { of origin; [ID] }\end{array}$ & Aim/purpose & $\begin{array}{c}\text { Conceptual description or } \\
\text { definition of frailty }\end{array}$ & $\begin{array}{l}\text { Operational definition of } \\
\text { frailty }\end{array}$ & $\begin{array}{l}\text { Sample } N \text {; age mean } \\
\text { (range) in years; } \\
\text { gender; race }\end{array}$ \\
\hline 10 & $\begin{array}{l}\text { Grenier, 2006; } \\
\text { social work; } \\
\text { Canada; [18] }\end{array}$ & $\begin{array}{l}\text { To explore the distinction } \\
\text { within older women's } \\
\text { narratives which represent a } \\
\text { clash between the } \\
\text { professional construct of } \\
\text { frailty and the lived } \\
\text { experiences of older } \\
\text { women. }\end{array}$ & $\begin{array}{l}\text { Frailty is contextually and } \\
\text { socially located; one aspect of } \\
\text { the person's appearance (i.e., } \\
\text { of "being frail") comes to } \\
\text { stand for the total identity. } \\
\text { "Being" frail is related to the } \\
\text { imposition of a classification } \\
\text { that is medical and functional } \\
\text { in nature; there are emotional } \\
\text { aspects of frailty that lie within } \\
\text { the experiences of } \\
\text { impairment, disability, and } \\
\text { decline in later life that may } \\
\text { contradict the medical and } \\
\text { social nature of frailty. } \\
\text { "Feeling" frail may or may not } \\
\text { correspond with experiences } \\
\text { of impairment or disability. } \\
\text { Certain events may trigger } \\
\text { frailty: new impairment, loss, } \\
\text { bereavement, evolving chronic } \\
\text { illness. }\end{array}$ & $\begin{array}{l}\text { Diverse older women in } \\
\text { sources of inequalities, e.g., } \\
\text { ability, age, race, ethnicity, } \\
\text { culture, and socioeconomic } \\
\text { status; six were considered } \\
\text { frail based on clinical } \\
\text { judgment and home care } \\
\text { eligibility and six women } \\
\text { were classified as not frail } \\
\text { because they did not receive } \\
\text { public services due to lack of } \\
\text { physical need, interest, or } \\
\text { financial resources to pay } \\
\text { privately. }\end{array}$ & $\begin{array}{l}N=12 \text {; not reported; } \\
12 \text { women; "diverse" }\end{array}$ \\
\hline 11 & $\begin{array}{l}\text { Hammar et al., } \\
\text { 2014; } \\
\text { neuroscience; } \\
\text { Sweden; [40] }\end{array}$ & $\begin{array}{l}\text { To explore experiences of } \\
\text { self-determination when } \\
\text { developing dependence in } \\
\text { daily activities among } \\
\text { community-dwelling } \\
\text { persons } 80 \text { years and older. }\end{array}$ & $\begin{array}{l}\text { Frailty is a continuum of } 3 \\
\text { phases: robust prefrail, fully } \\
\text { frail; a dynamic concept; } \\
\text { directly related to decreased } \\
\text { ability to perform daily } \\
\text { activities independently. }\end{array}$ & $\begin{array}{l}80 \text { years and older; frailty } \\
\text { based on eight frailty } \\
\text { indicators: weakness, } \\
\text { fatigue, weight loss, physical } \\
\text { activity, poor balance, slow } \\
\text { gait speed, visual } \\
\text { impairment, and cognition; } \\
\text { classified as nonfrail ( } 0 \\
\text { indicators), prefrail ( } 1-2 \\
\text { indicators), and frail ( } 3 \text { or } \\
\text { more indicators). }\end{array}$ & $\begin{array}{c}N=11 ; 87(84-95) ; 5 \\
\text { men, } 6 \text { women; } \\
\text { Caucasian }\end{array}$ \\
\hline 12 & $\begin{array}{l}\text { Jett, 2002; nursing; } \\
\text { USA; [20] }\end{array}$ & $\begin{array}{l}\text { To explore the process of } \\
\text { help-seeking and help } \\
\text { giving by older rural African } \\
\text { Americans and how certain } \\
\text { of the most vulnerable and } \\
\text { least known elders seek help } \\
\text { for day-to-day needs. }\end{array}$ & $\begin{array}{l}\text { Frailty not defined; survival of } \\
\text { frail elders and role of ADLs } \\
\text { and IADLs for day-to-day } \\
\text { functioning described; frail } \\
\text { elders are most vulnerable } \\
\text { with the least known needs } \\
\text { and at greater risk for losses } \\
\text { and unmet needs which can be } \\
\text { mitigated with help-seeking } \\
\text { behaviors. }\end{array}$ & $\begin{array}{c}\text { Age } \geq 65 \text { years, living alone, } \\
\text { and evidence of at least one } \\
\text { ADL (range } 6 \text { [complete } \\
\text { independence] to } 36 \\
\text { [complete dependence]) or } \\
\text { IADL deficit (range } 8 \\
\text { [complete independence] to } \\
24 \text { [complete dependence]), } \\
\text { and "knowledgeable about } \\
\text { aging and frailty." }\end{array}$ & $\begin{array}{l}N=41,9 \text { frail; not } \\
\text { reported; } 9 \text { women; } \\
\text { African American }\end{array}$ \\
\hline 13 & $\begin{array}{l}\text { Jett, 2003; nursing; } \\
\text { USA; [21] }\end{array}$ & $\begin{array}{l}\text { To examine the meaning of } \\
\text { aging from the perspective } \\
\text { of older African American } \\
\text { women living in rural areas. }\end{array}$ & $\begin{array}{l}\text { Frailty not defined; the study } \\
\text { focused on ethnography of the } \\
\text { aging, fragility, and survival of } \\
\text { rural elderly African } \\
\text { Americans and learning who } \\
\text { is identified as aged, how aging } \\
\text { is defined and culturally } \\
\text { determined, and what it } \\
\text { means to be old. }\end{array}$ & $\begin{array}{l}\text { Age } \geq 65 \text { years, living alone, } \\
\text { and frail based on at least } \\
\text { one ADL or IADL deficit; } \\
\text { ADL score: } 6 \text { (complete } \\
\text { independence) to } 36 \\
\text { (complete dependence), and } \\
\text { IADL score } 8 \text { (complete } \\
\text { independence) to } 24 \\
\text { (complete dependence). }\end{array}$ & $\begin{array}{c}N=9 ; 84(77-94) ; 9 \\
\text { women; African } \\
\text { American }\end{array}$ \\
\hline
\end{tabular}


TABle 1: Continued.

\begin{tabular}{|c|c|c|c|c|c|}
\hline & $\begin{array}{l}\text { First author, date; } \\
1^{\text {st }} \text { author } \\
\text { discipline; country } \\
\text { of origin; [ID] }\end{array}$ & Aim/purpose & $\begin{array}{c}\text { Conceptual description or } \\
\text { definition of frailty }\end{array}$ & $\begin{array}{l}\text { Operational definition of } \\
\text { frailty }\end{array}$ & $\begin{array}{l}\text { Sample } N \text {; age mean } \\
\text { (range) in years; } \\
\text { gender; race }\end{array}$ \\
\hline 14 & $\begin{array}{l}\text { Kaufman, 1994; } \\
\text { nursing; USA; [41] }\end{array}$ & $\begin{array}{l}\text { To investigate ways in which } \\
\text { frailty is defined, framed, } \\
\text { and understood by older } \\
\text { persons, their family } \\
\text { members, and healthcare } \\
\text { providers in the context of a } \\
\text { multidisciplinary geriatric } \\
\text { assessment service; to } \\
\text { explore the process of } \\
\text { increasing of frailty in } \\
\text { advanced old age, how they } \\
\text { attempt to understand, } \\
\text { accept, manage, and combat } \\
\text { frailty within the context of } \\
\text { the American healthcare } \\
\text { system and the mechanisms } \\
\text { employed to cope with and } \\
\text { solve the variety of } \\
\text { problems it creates. }\end{array}$ & $\begin{array}{c}\text { Frailty increases with } \\
\text { advancing age; a dynamic } \\
\text { adaptational process that is } \\
\text { open to multiple } \\
\text { interpretations. The } \\
\text { medicalization of frailty } \\
\text { overshadows psychological, } \\
\text { emotional, and behavioral } \\
\text { aspects of aging and frailty. } \\
\text { Frailty is socially produced in } \\
\text { response to powerful } \\
\text { discourses in American } \\
\text { culture. Frailty is proposed } \\
\text { when someone conceives } \\
\text { there to be a lived problem } \\
\text { with a very old person; either } \\
\text { the old person has a condition } \\
\text { that is worsening or spreading } \\
\text { to other body systems or areas } \\
\text { of the person's life, or family } \\
\text { members can no longer cope } \\
\text { with caring for the person and } \\
\text { focus on symptoms or } \\
\text { behaviors as problems. }\end{array}$ & $\begin{array}{l}\text { Age } \geq 80 \text { years; receiving } \\
\text { geriatric assessment } \\
\text { services; and perceived by } \\
\text { family members, friends, or } \\
\text { health professionals to be at } \\
\text { risk with a change in } \\
\text { condition, health decline, } \\
\text { and need for medical care, } \\
\text { social support, and/or } \\
\text { supervision so that they } \\
\text { could remain in the } \\
\text { community. }\end{array}$ & $\begin{array}{c}N=3 ; \geq 80 ; 3 \\
\text { women; not } \\
\text { reported }\end{array}$ \\
\hline 15 & $\begin{array}{c}\text { Kuo et al., 2012; } \\
\text { nursing; Taiwan; } \\
\text { [42] }\end{array}$ & $\begin{array}{l}\text { To cross-examine results } \\
\text { between perception of } \\
\text { frailty and physical } \\
\text { assessment outcomes then } \\
\text { try to establish frailty } \\
\text { indicators for elderly people } \\
\text { in Taiwan. }\end{array}$ & $\begin{array}{l}\text { Frailty indicates a dynamic } \\
\text { model and a balance of } \\
\text { psychological and physical } \\
\text { strength to counterthreats to } \\
\text { health; a decline in physical } \\
\text { reserve capacity and ability to } \\
\text { resist stress. }\end{array}$ & $\begin{array}{l}65 \text { years and older; Barthel } \\
\text { index for ADL, IADL, grip } \\
\text { strength (handheld } \\
\text { dynamometer), timed-up- } \\
\text { and-go test, paper folding } \\
\text { test, spirometry, vision test, } \\
\text { incontinence, body mass } \\
\text { index, waist-hip ratio, body } \\
\text { fat composition, Mini- } \\
\text { Mental State Exam, } \\
\text { Geriatric Depression Scale. }\end{array}$ & $\begin{array}{c}N=10 ; 69.5(65-74) \\
10 \text { women; Asian }\end{array}$ \\
\hline 16 & $\begin{array}{l}\text { Moss et al., 2007; } \\
\text { sociology/ } \\
\text { anthropology; } \\
\text { USA; [43] }\end{array}$ & $\begin{array}{l}\text { To learn the meanings and } \\
\text { themes that underlie } \\
\text { attitudes of frail old men } \\
\text { who live in the community } \\
\text { and behaviors in relation to } \\
\text { food and eating. }\end{array}$ & Not described. & $\begin{array}{l}\text { Frailty based on eight-item } \\
\text { screener of mobility (e.g., } \\
\text { use of walker or wheelchair) } \\
\text { and activities of daily living } \\
\text { (e.g., meal preparation, light } \\
\text { housework, and bathing). }\end{array}$ & $\begin{array}{l}N=21 ; 83(76-95) \\
11 \text { men, } 10 \text { women; } \\
12 \text { Caucasian, } 3 \\
\text { African American }\end{array}$ \\
\hline 17 & $\begin{array}{c}\text { Nicholson et al., } \\
\text { 2012; nursing; } \\
\text { United Kingdom; } \\
\text { [22] }\end{array}$ & $\begin{array}{l}\text { To understand the } \\
\text { experience of home- } \\
\text { dwelling older people living } \\
\text { with frailty over time in } \\
\text { order to develop the } \\
\text { empirical evidence base for } \\
\text { this group and to consider } \\
\text { more fully how narratives of } \\
\text { frailty can shape person- } \\
\text { centered care provision. }\end{array}$ & $\begin{array}{l}\text { Frailty is an antonym for } \\
\text { successful aging and a } \\
\text { synonym for the increasing } \\
\text { infirmities that accompany } \\
\text { aging and the slow dwindling } \\
\text { dying trajectory of many } \\
\text { elders. This trajectory is } \\
\text { gradual and unpredictable, } \\
\text { encompassing accumulated } \\
\text { and multiple health problems, } \\
\text { which at some point tips the } \\
\text { person into the dying phase. } \\
\text { The social construction of the } \\
\text { fourth age as a loss of agency } \\
\text { and bodily self-control is } \\
\text { linked to frailty. }\end{array}$ & $\begin{array}{l}\text { Frail persons were defined } \\
\text { by the interdisciplinary care } \\
\text { team based on advancing } \\
\text { age, unable to carry out } \\
\text { IADLs and considered to be } \\
\text { vulnerable to physical } \\
\text { decline. }\end{array}$ & $\begin{array}{c}N=17 ; 94(86-102) \\
5 \text { men, } 12 \text { women; } \\
\text { Caucasian }\end{array}$ \\
\hline
\end{tabular}


TABle 1: Continued.

\begin{tabular}{|c|c|c|c|c|c|}
\hline & $\begin{array}{l}\text { First author, date; } \\
1^{\text {st }} \text { author } \\
\text { discipline; country } \\
\text { of origin; [ID] }\end{array}$ & Aim/purpose & $\begin{array}{l}\text { Conceptual description or } \\
\text { definition of frailty }\end{array}$ & $\begin{array}{l}\text { Operational definition of } \\
\text { frailty }\end{array}$ & $\begin{array}{l}\text { Sample } N \text {; age mean } \\
\text { (range) in years; } \\
\text { gender; race }\end{array}$ \\
\hline 18 & $\begin{array}{c}\text { Nicholson et al., } \\
\text { 2013; nursing; } \\
\text { United Kingdom; } \\
\text { [23] }\end{array}$ & $\begin{array}{c}\text { To understand the } \\
\text { experience over time of } \\
\text { home-dwelling older people } \\
\text { deemed frail, in order to } \\
\text { enhance the evidence base } \\
\text { for person-centered } \\
\text { approaches to frail elder } \\
\text { care. }\end{array}$ & $\begin{array}{l}\text { Frailty describes the condition } \\
\text { of people vulnerable to } \\
\text { adverse health outcomes in } \\
\text { later life and includes a } \\
\text { broader definition that } \\
\text { includes social functioning, } \\
\text { social relationships, and } \\
\text { psychological frailty, e.g., } \\
\text { anxiety and loneliness } \\
\text { encompassing social, } \\
\text { psychological, and physical } \\
\text { domains. }\end{array}$ & $\begin{array}{c}\text { Frail elders were } \\
\text { purposively selected by the } \\
\text { multidisciplinary care team } \\
\text { (community nurses, speech } \\
\text { therapist, physiotherapists, } \\
\text { occupational therapists, } \\
\text { care support workers, } \\
\text { geriatricians) based on age } \\
\geq 85 \text { year, unable to carry out } \\
\text { IADLs and considered to be } \\
\text { vulnerable to physical } \\
\text { decline. }\end{array}$ & $\begin{array}{c}N=15 ; 94(86-102) ; \\
5 \text { men, } 10 \text { women; } \\
\text { Caucasian }\end{array}$ \\
\hline 19 & $\begin{array}{l}\text { Niesten et al., 2012; } \\
\text { dental science; } \\
\text { Netherlands; [25] }\end{array}$ & $\begin{array}{l}\text { To identify and examine } \\
\text { how natural teeth } \\
\text { contribute to the quality of } \\
\text { life of dentulous people who } \\
\text { are elderly and frail and how } \\
\text { frailty influences the impact } \\
\text { of having natural teeth on } \\
\text { quality of life. }\end{array}$ & $\begin{array}{l}\text { Frailty is a state of reduced } \\
\text { psychological or physical } \\
\text { reserve in combination with } \\
\text { an increased risk for adverse } \\
\text { outcomes such as falls, } \\
\text { disability, and } \\
\text { institutionalization. Frailty } \\
\text { impacts health in general and } \\
\text { the value that people ascribe to } \\
\text { their oral health and their } \\
\text { subjective dental care needs } \\
\text { and demands. }\end{array}$ & $\begin{array}{l}\text { Age } \geq 65 \text { years and frailty } \\
\text { score based on eight } \\
\text { domains: social coping, } \\
\text { psychosocial function, } \\
\text { personal care, mobility, } \\
\text { motor function, medical } \\
\text { care, behavior disorders, } \\
\text { and care needs per week. } \\
\text { Score ranged from } 0 \text { to } 10, \\
\text { where score of "1" indicated } \\
\text { mild frailty and "6" severe } \\
\text { frailty; persons scoring } 7-10 \\
\text { were excluded. Scoring was } \\
\text { determined by a medical } \\
\text { authority. }\end{array}$ & $\begin{array}{c}N=38 ; 79.9(65-97) ; \\
11 \text { men, } 27 \text { women; } \\
2 \text { Indonesian } \\
\text { women, } 25 \\
\text { Caucasian women, } \\
\text { and } 11 \text { Caucasian } \\
\text { men. }\end{array}$ \\
\hline 20 & $\begin{array}{l}\text { Niesten et al., 2013; } \\
\text { dental science; } \\
\text { Netherlands; [24] }\end{array}$ & $\begin{array}{c}\text { To explain how frailty } \\
\text { influences dental service use } \\
\text { and oral self-care by older } \\
\text { people. }\end{array}$ & $\begin{array}{c}\text { A state of reduced } \\
\text { psychological or physical } \\
\text { reserve in combination with } \\
\text { an increased risk for adverse } \\
\text { outcomes such as falls, } \\
\text { disability, and } \\
\text { institutionalization; a dynamic } \\
\text { state affecting an individual } \\
\text { who experiences losses in one } \\
\text { or more domains of human } \\
\text { functioning (physical, } \\
\text { psychological, social) which } \\
\text { likely negatively affects dental } \\
\text { service use and oral hygiene- } \\
\text { related behaviors. }\end{array}$ & $\begin{array}{l}\text { Age } \geq 65 \text { years and a frailty } \\
\text { score based on eight } \\
\text { domains: Social coping, } \\
\text { psychosocial function, } \\
\text { personal care, mobility, } \\
\text { motor function, medical } \\
\text { care, behavior disorders, } \\
\text { and care needs per week. } \\
\text { Score ranges from } 0 \text { to } 10, \\
\text { where scores of "1" } \\
\text { indicated mild frailty and } \\
\text { "6" severe frailty; persons } \\
\text { scoring } 7-10 \text { excluded. } \\
\text { Scoring determined by a } \\
\text { medical authority. }\end{array}$ & $\begin{array}{l}N=51 ; 24 \text { being } \\
65-80,27 \text { being } \geq 80 \\
\text { years; } 16 \text { men, } 35 \\
\text { women; not } \\
\text { reported }\end{array}$ \\
\hline 21 & $\begin{array}{l}\text { O’Connor, 1994; } \\
\text { social work; } \\
\text { England; [44] }\end{array}$ & $\begin{array}{l}\text { To recognize the affective } \\
\text { reality of elderly persons' } \\
\text { experiences in the life } \\
\text { review of frail elderly people } \\
\text { who are living alone. }\end{array}$ & $\begin{array}{l}\text { Frail elderly people who are } \\
\text { living alone, housebound, } \\
\text { and/or in need of assistance } \\
\text { with basic activities of daily } \\
\text { living and/or have emotional } \\
\text { and/or social problems (which } \\
\text { may include perceived } \\
\text { inability to care for } \\
\text { themselves) are in a socially } \\
\text { vulnerable position. }\end{array}$ & $\begin{array}{l}\text { Randomly selected } \\
\text { homebound social work } \\
\text { clients who need ADL } \\
\text { assistance. Frailty markers } \\
\text { to describe the sample: } \\
\text { falling in the past year, } \\
\text { having partial or total loss of } \\
\text { use of an arm or a leg, prone } \\
\text { to heart attacks and/or acute } \\
\text { attacks of bronchitis or } \\
\text { asthma, unable to get out of } \\
\text { bed, walk indoors or } \\
\text { outside, climb stairs, and/or } \\
\text { bathe. }\end{array}$ & $\begin{array}{l}N=134 ; \geq 65 ; 28 \\
\text { men, } 114 \text { women; } \\
\text { not reported }\end{array}$ \\
\hline
\end{tabular}


TABle 1: Continued.

\begin{tabular}{|c|c|c|c|c|c|}
\hline & $\begin{array}{l}\text { First author, date; } \\
1^{\text {st }} \text { author } \\
\text { discipline; country } \\
\text { of origin; [ID] }\end{array}$ & Aim/purpose & $\begin{array}{c}\text { Conceptual description or } \\
\text { definition of frailty }\end{array}$ & $\begin{array}{l}\text { Operational definition of } \\
\text { frailty }\end{array}$ & $\begin{array}{l}\text { Sample } N \text {; age mean } \\
\text { (range) in years; } \\
\text { gender; race }\end{array}$ \\
\hline 22 & $\begin{array}{l}\text { Porter, 1999; } \\
\text { nursing; USA; [26] }\end{array}$ & $\begin{array}{l}\text { To explore a neglected realm } \\
\text { of frail older women's } \\
\text { experience of falling to the } \\
\text { floor and trying to get up } \\
\text { while at home alone. }\end{array}$ & $\begin{array}{l}\text { Not defined, but it was stated } \\
\text { that frail older persons are at } \\
\text { risk for falls and participants } \\
\text { had physical function deficits } \\
\text { that were indicators of frailty. }\end{array}$ & $\begin{array}{l}\text { Women aged } 80 \text { years and } \\
\text { older, living alone at home, } \\
\text { self-rated health of less than } \\
\text { excellent, history of a fall. } \\
\text { Frailty determined by three } \\
\text { criteria: inability to walk } 10 \\
\text { blocks, need for assistance } \\
\text { to climb stairs, and need for } \\
\text { assistive device to walk. }\end{array}$ & $\begin{array}{c}N=18 ; 89.5(83-96) ; \\
\text { all women; not } \\
\text { reported }\end{array}$ \\
\hline 23 & $\begin{array}{l}\text { Puts et al., 2009; } \\
\text { nursing; } \\
\text { Netherlands; [28] }\end{array}$ & $\begin{array}{l}\text { To describe the meaning } \\
\text { that older community- } \\
\text { dwelling persons attach to } \\
\text { frailty. }\end{array}$ & $\begin{array}{c}\text { Frailty is often used to } \\
\text { describe a state in which older } \\
\text { persons are, in a delicate } \\
\text { balance, at risk for many } \\
\text { adverse outcomes such as falls, } \\
\text { disability, institutionalization, } \\
\text { and death, which may have a } \\
\text { negative effect on quality of } \\
\text { life. }\end{array}$ & $\begin{array}{l}\text { Frailty determined by eight } \\
\text { frailty markers: low body } \\
\text { mass index, low peak } \\
\text { expiratory flow, poor vision } \\
\text { and hearing ability, } \\
\text { incontinence, low sense of } \\
\text { mastery, depressive } \\
\text { symptoms, and physical } \\
\text { inactivity. Frailty defined as } \\
\text { having three or more } \\
\text { markers and nonfrail } \\
\text { defined as no frailty } \\
\text { markers. }\end{array}$ & $\begin{array}{c}N=25 ; 78.7(67-90) ; \\
14 \text { men, } 11 \text { women; } \\
\text { Caucasian }\end{array}$ \\
\hline
\end{tabular}

Frailty determined by eight frailty markers: low body mass index, low peak expiratory flow, poor vision and hearing ability, Puts et al., 2007; quality of life from the are in a delicate balance and at perspective of frail and nursing; 24 Netherlands; [29] nonfrail older communitydwelling persons in Netherlands. risk for many adverse disability, institutionalization, and death. outcomes such as falls, incontinence, low sense of $N=25 ; 78.7$ (67-90); mastery, depressive symptoms, and physical inactivity. Frailty defined as having three or more markers and nonfrail defined as no frailty markers.
14 men, 11 women;

Caucasian
Age 65 years and older. Frailty based on Fried frailty criteria: weakness (handgrip strength), exhaustion, weight loss, physical activity, gait speed, and cognition (Mini-Mental State Exam); classified as nonfrail (0 indicators), prefrail (1-2 indicators), or frail (3 or more indicators).
$N=29 ; 76.3(>65) ; 8$ men, 21 women; Caucasian (21), African American (7), other (1)

\begin{abstract}
5 2018; medicine;
USA; [45]

informational needs about frailty among older adults.
\end{abstract} death.

symptoms, leading to multiple adverse outcomes including functional dependence, and 
TABLE 2: Quality appraisal: CASP Qualitative Studies Checklist and evaluative criteria.

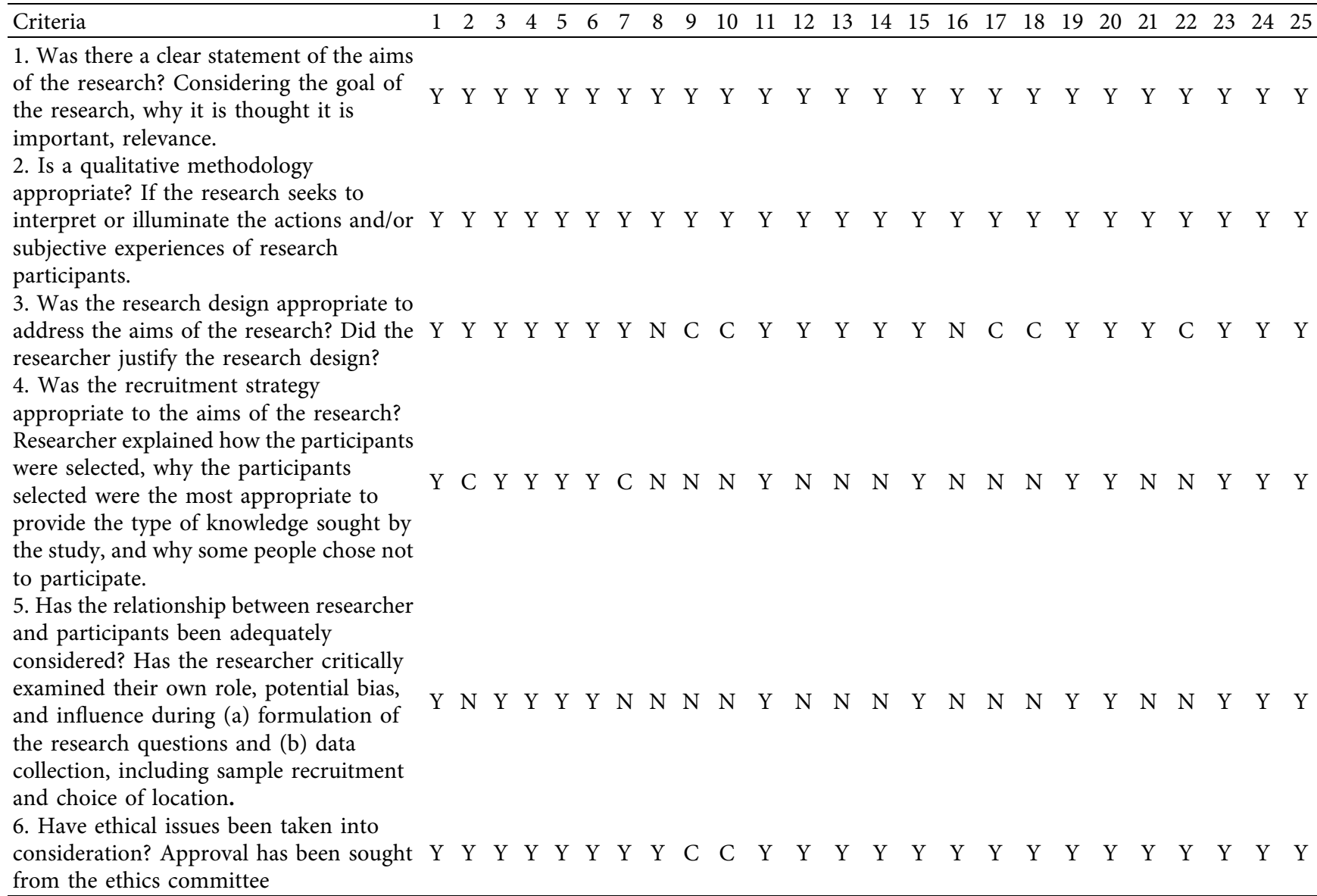

Rating: Y:yes; N: no; C: cannot answer. CASP: Critical Appraisal Skills Programme, https://casp-uk.b-cdn.net/wp-\%20content/uploads/2020/10/ CASP_RCT_Checklist_PDF_Fillable_Form.pdf.

timed-up-and-go test, chair stands, and gait speed [3]; however, information about the tool and its scoring was absent. Measures for psychological function (e.g., cognition and mood) were included in seven articles, whereas three articles incorporated social factors such as living alone, social isolation, social support, and hours of care needed. Eight articles differentiated frail and nonfrail status $[24,25,28,29,34,36,40,45]$.

3.4. Synthesis of Conceptual Definitions of Frailty. How researchers conceptually defined frailty in the qualitative research studies was examined using concept mapping. Synthesis of the 25 articles in this review yielded 10 categories and four themes: Time, Vulnerability, Loss, and Relationships. The themes, categories, and exemplar statements are summarized in Table 4. Figure 2 provides an example of concept mapping and data reduction for one of the themes, and Figure 3 provides a graphical display of the concept map for the four themes.

3.4.1. Theme 1: Time. Time was characterized by older age, aging process, dynamic trajectory, and progressive physiologic dysregulation. Frailty as an age-related and progressive condition was temporally described as an evolving trajectory with accumulation of health problems and impairments. Frailty was also characterized as a dynamic state that follows a continuum from robust to end-of-life. There is also a tipping point in the frailty trajectory in which the accumulated burden of disease and psychosocial challenges lead to transition from frailty risk to frailty as a reality. Transitional points on the frailty continuum signal opportunities to prevent, delay, or reverse frailty and accelerate its progression.

3.4.2. Theme 2: Vulnerability. Vulnerability was portrayed as impaired resilience, a precarious state, and psychological and social coping. Frailty is highly unstable and unpredictable, with waning reserve, loss of resilience, and reduced capacity to resist stressors. Frailty is marked by increased risk for adverse outcomes, with differential risk appreciated in marginalized, minority, and immigrant populations and subgroups of older men and women. Frailty is a personal, subjective experience that could be triggered or worsened by negative emotions such as worry, sadness, fear, and anger. Psychological vulnerability arising from negative emotional experiences supersedes the physical experience and increases the risk for frailty. Social vulnerability was characterized by 
TABLE 3: Quantitative measurement of frailty in qualitative research studies $(N=13)$.

\begin{tabular}{|c|c|c|c|c|c|}
\hline $\begin{array}{l}\text { Author, year; frailty cut } \\
\text { point }\end{array}$ & Physical performance tests & $\begin{array}{l}\text { Cognition } \\
\text { function }\end{array}$ & $\begin{array}{l}\text { Mood-self- } \\
\text { report }\end{array}$ & Metrics & Self-report questionnaire \\
\hline
\end{tabular}

TFI: physical domain (feeling healthy, weight loss, vision, hearing, walking, balance,

Andreasen et al., 2015;

frailty $=5 / 15$ hand strength, tiredness),

psychological domain

(memory, mood, anxiety, coping), social domain (living alone, social isolation, social support)

\begin{tabular}{|c|c|c|c|c|}
\hline $\begin{array}{l}\text { Claassens et al., 2014; } \\
\text { frailty }=2 / 6\end{array}$ & $\begin{array}{c}\text { Grip strength, vision, } \\
\text { hearing }\end{array}$ & MMSE & BMI & Physical activity \\
\hline $\begin{array}{l}\text { Hammar et al., 2014; } \\
\text { frailty }=3 / 8 \text { indicators }\end{array}$ & $\begin{array}{l}\text { Grip strength, gait speed, } \\
\text { balance, vision }\end{array}$ & MMSE & & $\begin{array}{l}\text { Endurance/physical activity, } \\
\text { fatigue, weight loss }\end{array}$ \\
\hline $\begin{array}{l}\text { Jett, 2002; } 2003 \text { frailty } \\
\text { cut point= one ADL } \\
\text { deficit }\end{array}$ & & & & $\begin{array}{c}\text { ADL and IADL, measurement } \\
\text { not specified }\end{array}$ \\
\hline
\end{tabular}

deficit

Barthel index for ADL,

Kuo et al., 2012; frailty cut point not specified up-and-go test, vision,
IADL, grip strength, timed hearing, paper folding test, spirometry

Niesten et al., 2012, 2013; slight, moderate, severe frailty based on level of care needed

Porter et al., 1999, 2001; measurement not specified
BMI, waist-hip composition

\section{MMSE GDS ratio, body fat Incontinence \\ MMSE GDS ratio, body fat Incontinence} . 
TABLE 4: Frailty concept map themes, categories, and statements.

\begin{tabular}{|c|c|c|}
\hline \multicolumn{3}{|r|}{ Frailty } \\
\hline Theme & Category & Sample statements \\
\hline \multirow{5}{*}{ Time } & Older age and aging process & $\begin{array}{l}\text { Risk for frailty is age-related and increases over time } \\
\text { Over age 80; greater than } 65 \text { years; "old-old"; fourth age } \\
\text { Aberrancies in biologic and physiologic systems lead to frailty } \\
\text { Gradual and unpredictable in the aging process }\end{array}$ \\
\hline & \multirow[t]{2}{*}{$\begin{array}{l}\text { Progressive physiologic } \\
\text { dysregulation }\end{array}$} & $\begin{array}{l}\text { Aging and impaired homeostasis and defense mechanisms adversely impact function } \\
\text { Ambiguous boundaries and cause-effect relationships exist between morbidity, } \\
\text { disability, and frailty }\end{array}$ \\
\hline & & $\begin{array}{l}\text { Progressive, time-dependent changes in structure and function } \\
\text { Malleable and may be prevented, mitigated, or reversed }\end{array}$ \\
\hline & \multirow[t]{2}{*}{ Dynamic trajectory } & $\begin{array}{c}\text { Frailty usually worsens over time; slow dwindling dying trajectory } \\
\text { Transitional; constantly changing and evolving }\end{array}$ \\
\hline & & Exists on a continuum from robust to end-of-life \\
\hline
\end{tabular}

Biopsychosocial domains of function

Relationships

Quality of life and well-being

Connections and interdependence

Physical function decline

Loss Cascading pathway with negative consequences

Psychological and social identity

Impaired resilience

Vulnerability Precarious state

Psychologic and social coping
Domains are interrelated; mutually interacting and inextricably linked; adverse events in one domain impact the other domains

Frailty is used to classify people to prioritize care and health and social services Frailty has many forms due to deficits in biopsychosocial domains of function Blurred boundaries between frail and nonfrail state; distinctions between feeling frail and being frail

Frailty is a threat to emotional integration and wholeness

Frailty is associated with social isolation, weakened social position Unstable social support or psychological states can precipitate or worsen frailty Dependence/interdependence between social network, services, resources, technology Transactional process requiring negotiation of interdependency and care receiving needs

Failed adaptation to manage frailty and changing biopsychosocial needs

Observable frailty markers: weight loss, weakness, low energy, unstable balance, slow movement, and mobility aids

Accumulation of chronic diseases

Sensory losses in vision or hearing

Losses are exacerbated across biopsychosocial domains of function Leads to impaired physical mobility and dependence

Falls, disability, hospitalization, institutionalization, quality of life, self-care deficits, early mortality

Stigma and negative connotations and labeling as frailty erode self-esteem and threaten identity

Medical classification denies psychological and social aspects Disempowerment; loss of autonomy, control, and inner drive

Reduced reserve capacity and ability to resist and overcome intrinsic and extrinsic stressors

Failing homeostasis and risk for adverse outcomes Increased healthcare needs and utilization Instability, uncertainty, fragility

Delicate balance and tipping point; fragility

Frailty precipitates increased healthcare needs and service utilization

Negative emotional reactions to frailty; diminished autonomy

High psychological and social support needs; negatively impacted by social isolation, living alone

Antonym for successful aging 


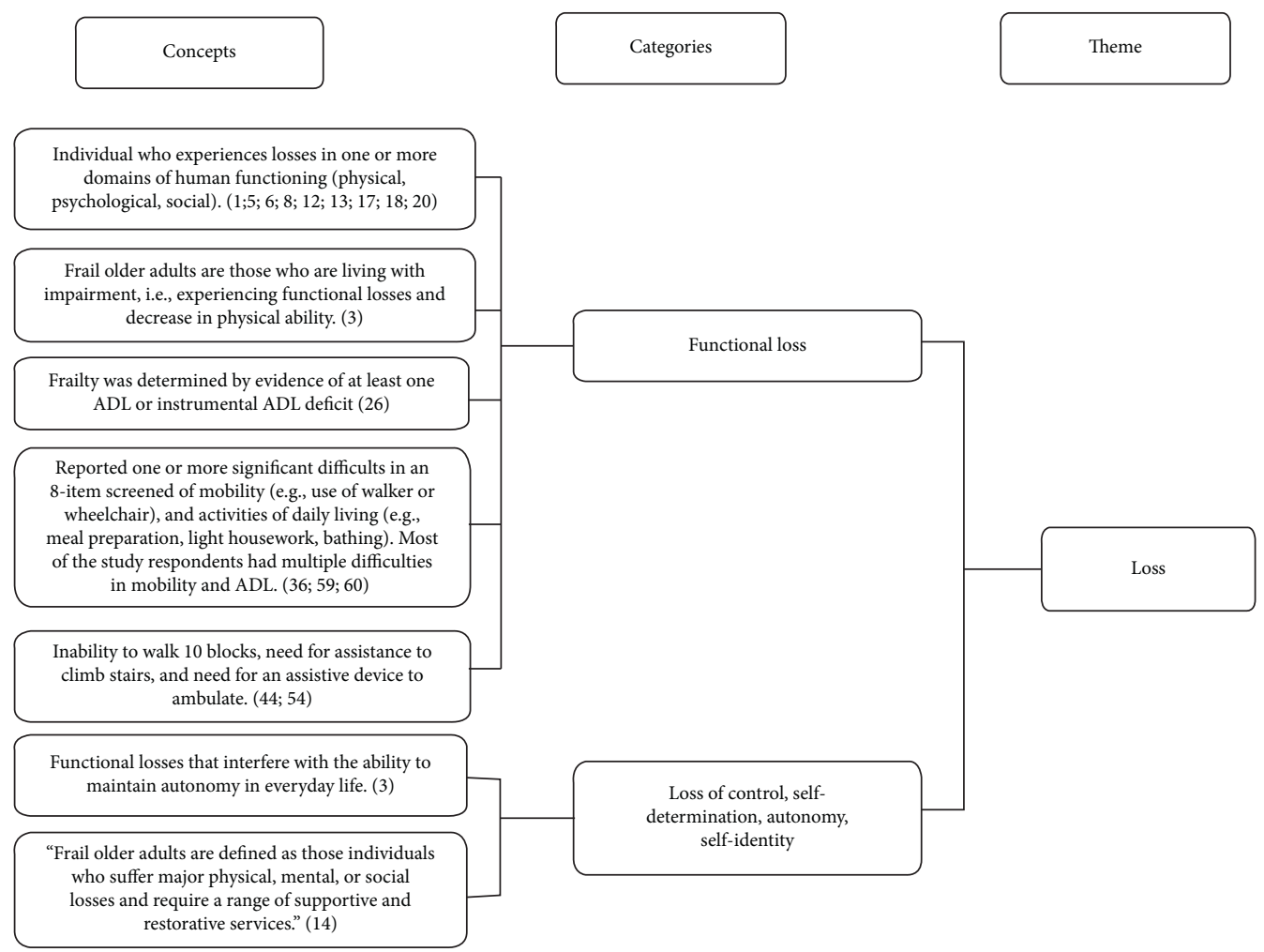

Figure 2: Data aggregation and classification of concepts into categories and themes.

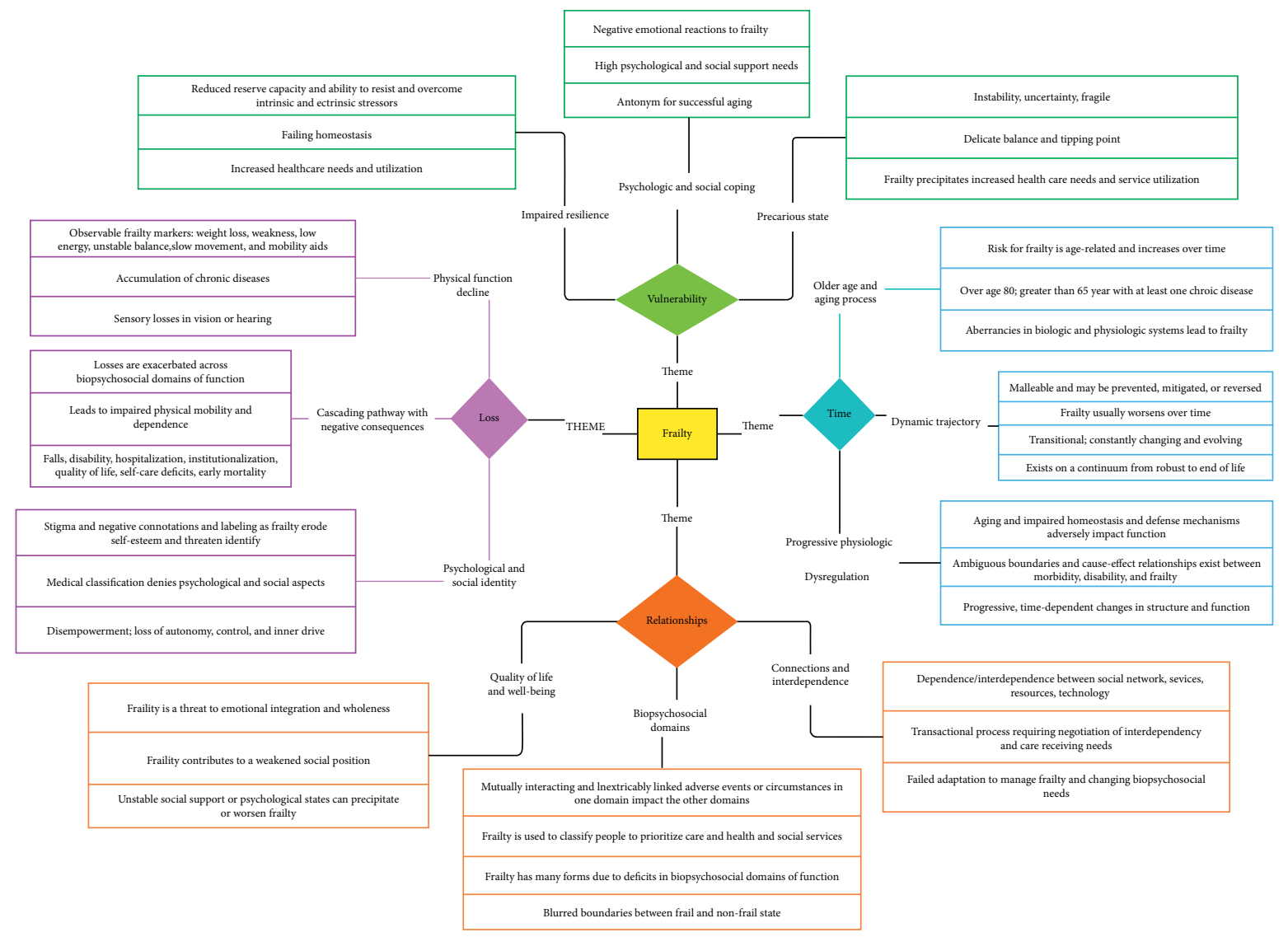

FIGURE 3: Concept map for frailty from the synthesis. 
Frailty threatens quality of life through compromised emotional integration, unstable social support, and weakened social position: frailty affects not only the individual, but also the social network and requires new connections to manage changing needs.

\section{Discussion}

4.1. Concordance in Conceptual Definitions of Frailty. In this qualitative systematic review of 25 articles, researchers conceptually defined frailty as a complex, multidimensional syndrome that evolves from underlying vulnerability, physiologic derangements, and loss of resilience manifested through dynamic interactions across the biopsychosocial domains of human function with greater risk for adverse outcomes. The four themes yielded in the synthesis identified concepts that align with the WHO Clinical Consortium on Healthy Aging Report [1] in which frailty is "...a clinically recognizable state in which the ability of older people to cope with every day or acute stressors is compromised by an increased vulnerability brought by age-associated declines in physiological reserve and function across multiple organ systems" (p. viii). Similarly, a concept analysis of frailty in the quantitative literature defined frailty as a tenuous state of health resulting from the complex interplay of physiological, psychosocial, and environmental stressors and is associated with numerous adverse health outcomes [46]. The conceptual definitions of frailty elaborated by researchers in the synthesis highlight human wholeness and the fact that psychological and social factors are as important as physical factors in frailty [47]. This evidence supports the growing body of evidence that articulates the relevance of a biopsychosocial model for frailty and provides a basis for moving away from organ- and disease-based approaches to frailty toward a more holistic, health- and wellness-based approach in geriatric care $[1,6,7]$.

4.2. Methodological Deficits. A major finding is that many articles in this systematic review suffered from poor methodological quality. Lack of specificity in detailing how frailty was operationally defined raised questions as to whether the study population was frail. The quality appraisal using the CASP checklist determined over half of the articles $(n=13)$ could be considered biased and potentially ageist due to reliance on age and physical impairments as primary frailty criteria; there is strong evidence that all older adults who experience physical limitations are not frail [5]. Qualitative investigations can improve the description of a complex, real-world phenomenon such as frailty. However, if study participants are misjudged as frail, their reflections on frailty would be based on their own opinions and not personal, direct experience, which threatens the veracity of the findings.

To our knowledge, this qualitative systematic review provides the first synthesis of conceptual and operational definitions of frailty that were used for participant selection in qualitative research on the experience of living with frailty among frail community-living older adults. Recent similar efforts have been undertaken in the quantitative literature.
Yaksic et al. [48] found that, out of 490 research study abstracts reviewed, only 348 (16\%) had a complete definition of frailty that included the name of the frailty measure, the variables used in the measure, and the scoring for levels of frailty. In a systematic review of frailty definitions applied in 78 quantitative research studies, Junius-Walker et al. [46] found that many studies lacked clear frailty definitions and inclusion criteria and recommended five components that constituted a comprehensive definition of frailty. In agreement with our findings, these investigators endorsed concepts such as multiple dimensions of frailty, emphasis on a function focused, holistic approach, intrinsic vulnerability and capacities, and interacting environmental factors that influence frailty over a focus on the physical and biological aspects [49]. Sezgin et al. [50] conducted a systematic review and thematic analysis of frailty definitions in quantitative research and review articles $(N=86)$ and found an overemphasis on physical aspects of frailty with few studies addressing psychosocial domains; here, only three studies were cited from the qualitative literature. Taken together, this body of work, including the present systematic review, reinforces the importance of clearly defining and operationalizing frailty in qualitative research as this will facilitate accurate interpretation of study findings and facilitate the transferability of this knowledge in future research and clinical practice. Articulating specific inclusion criteria is important in qualitative research because it helps ensure that participants can provide the information necessary to address the research question and facilitates cross-study comparisons [51]. Deficits in participant sampling limits the number of qualitative research studies that would be eligible for inclusion in a qualitative metasynthesis, which is a mechanism to aggregate findings from qualitative research in order to yield new information [10].

4.3. Older Chronological Age as Synonymous with Frailty. Although research indicates that advancing age increases risk for frailty, chronologic age is only loosely correlated with biological age and is not the most reliable indicator for frailty [4]. In addition, although older age, comorbidity, and disability may overlap in the frailty experience, particularly in more advanced stages, they are distinctly different $[52,53]$. Similarly, while advanced age brings a higher likelihood of multiple and interacting chronic diseases that may lead to frailty, it is notable that not all older people with comorbidity are frail, and younger persons may experience frailty $[2,54,55]$. Importantly, a hallmark of aging is the wide diversity of the aging experience; there is no typical older person [1]. Frailty is also found in middle-aged adults, especially minority groups such as African Americans where frailty not only develops earlier but also follows a more severe course due to health disparities and disadvantages in opportunities for developing healthy lifestyles and good health across the life course $[1,2]$. Accelerated aging and frailty may be evidenced in individuals younger than 70 years due to health disparities arising from economic, educational, and health disadvantages in contrast to more robust 85 -year-old individuals with lifelong access to 
resources and healthy lifestyles [56]. Thus, qualitative research that studies frailty only in older adults risks failing to detect frailty in younger, vulnerable populations who may experience different health circumstances and a steeper frailty trajectory [56].

4.4. Physical Impairment. The most common operational definition of frailty in this review focused primarily on physical function and limitations in activity of daily living. This finding contrasts with investigations and position papers that articulate distinctions between frailty and disability [5, 53]. An interdisciplinary consensus conference of international experts conferred that the most often used definition of physical frailty involved the evaluation of five physical-function-related domains (nutrition, energy, physical activity, mobility, strength) to identify older adults at high risk for adverse health outcomes; however, there was agreement that frailty is different from disability until its later stages [57]. Deficits in physical function often accompany comorbidities and may also be due to barriers in physical environments.

4.5. Holistic, Biopsychosocial Perspectives on Frailty. Despite the predominance of older age and physical impairments as key empirical indicators for frailty in this review, the conceptual definitions and descriptions of frailty in the qualitative research studies endorsed a more holistic perspective that recognizes the psychosocial domains in the scientific literature on frailty assessment $[5,6,46,51]$ although there is no agreement on which indicators [58-60]. Psychosocial factors such as depression, anxiety, quality of life, stressful life events, and resilience are recognized as correlates of frailty [47]. Cognitive frailty is characterized by the cooccurrence of physical frailty and cognitive impairment [61]. Social frailty is the accumulation of multiple social risk factors related to socioeconomic status, social support, social engagement, and social behaviors that can adversely impact health outcomes [62].

Notably, none of the articles in this review included spirituality as a factor in frailty, although research indicates that spirituality may be an important aspect of psychological health that moderates the negative effects of frailty [63]. Spirituality may be especially salient in certain population; for example, in a study using focus groups of African American men and women, spirituality was identified as a significant driver in the prevention and mitigation of frailty [64]. Qualitative research on frailty assessment that incorporates measures for psychosocial function and spirituality is needed, because frailty is about not only physical changes but also psychological, social, and spiritual factors that may precipitate and mediate such changes.

4.6. Empirical Indicators of Frailty. There is continued debate about the ideal frailty assessment that is applicable in research and clinical practice. In the scientific literature, frailty has been operationally defined in three major frameworks: (1) the phenotype for physical frailty quantified by objective criteria and performance-based measures (e.g., weight loss, weakness, exhaustion, slowness, and low physical activity) [53]; (2) according to a deficit accumulation framework represented by the proportion of a range of deficits (30-70) that are present, which reflects greater frailty $[65,66]$; and (3) as a multidimensional biopsychosocial construct based on comprehensive geriatric assessment [7]. The present systematic review included articles dating back to 1994 since the search strategy extended to database inception. While this allowed for a broad representation of articles for the synthesis, methodologies for both qualitative research and frailty assessment have changed. More recent articles included empirical indicators and quantitative measures for frailty, such as handgrip strength, gait speed, and validated chair stand tests for frailty with demonstrated predictive properties [3]. Several articles in this review included tests for vision and hearing since there is evidence linking frailty and sensory deficits [67]. However, measures for pulmonary function such as spirometry and peak expiratory flow were used in two articles without justification for their relevance to frailty. Tests for cognitive function and mood were also used in some of the more contemporary articles. Increasingly, opinions about frailty in the scientific literature indicate that focusing exclusively on physical frailty hinders a full understanding of frailty and its impact on the individual [68].

4.7. Racial, Ethnic, and Cultural Diversity. Although the articles in this review displayed some cultural diversity by authorship and country of origin, cultural aspects of frailty were addressed in only two articles that included African American participants [20, 21]. These findings concur with recent systematic reviews of frailty that observe deficits in addressing cultural factors in definitions of frailty in the quantitative literature $[49,50]$. A study that translated the Tilburg Frailty Indicator for use in the Jordanian population found that the psychometric properties were similar for physical frailty, but not for psychological or social frailty; thus, modification for cultural relevance was required [69]. For example, in Jordanian culture, close-knit families help compensate for the decline in aging and frailty; thus, to be consistent with Jordanian culture, items such as "Do you live alone?" and "Do you sometimes miss having people around you?" were revised as "Have you felt alone?" because older adults often live with family members [69]. In a study of older Taiwanese adults, feedback about a frailty assessment tool determined that they felt it was not effective in addressing quality of life [70]. Future research is needed to ensure that frailty measures used in qualitative research are culturally and socially relevant and sensitive to variations in life experience to more comprehensively assess the frailty experience.

4.8. Stigma Associated with Frailty. One interesting finding in this review was the extent to which researchers discussed negative connotations and stigma associated with frailty $[18,19,21,23,35,38,39,41] 2003$. Stigma is the co-occurrence of labeling, stereotyping, separation, status loss, and discrimination and may result in feelings of shame, fear, guilt, suffering, depression, isolation, reluctance to seek treatment, and decreased self-esteem [71]. The language of 
frailty used to classify a person's health status is socially constructed based on prevailing norms and stereotypes and may have a detrimental impact on the individual due to stigma. In recent initiatives by Age UK and British Geriatrics Society [8] to address the public health impact of frailty, the "Fit for Frailty" campaign reported that the vocabulary of frailty was a barrier to involving older individuals in their care. While there is utility for the term frailty, there is a need to change how it is viewed and talked about by using different terminology [9]. Furthermore, negative emotions engendered by the term frailty that is used in participant recruitment may also hinder participation in research. Nonstigmatizing synonyms for frailty are needed to facilitate communication and recruitment in research contexts, since the term frailty may offend, frighten, or turn away potential participants. Several strategies are recommended for communicating with frail individuals that include avoidance of the term "frailty" and using language that promotes independence, enablement, and resilience $[68,72]$. The concept of intrinsic capacity as posited by the World Health Organization is central to the prevention and mitigation of frailty; dialogue that frames frailty using perspectives of empowerment, capacity, and capability may foster resilience and resistance to frailty [1]. Public service messaging and health education should be tailored for subgroups based on gender, since the frailty experience among men and women differs [47]. Qualitative research can elaborate on these issues and uncover how resilience mediates frailty and identify terminology to incorporate a broader and more balanced understanding of frailty $[68,72]$.

The purpose of this review was not to discern or endorse a definition of frailty, but to represent how it is defined in qualitative research for participant selection inclusion criteria. Qualitative research including metasynthesis of qualitative research findings can inform understanding of a complex, ambiguous phenomenon such as frailty and contribute new knowledge about this condition from insights provided by the persons who are affected by it. Future research is needed in different age, racial, ethnic, and cultural groups to elucidate what is frailty, how a person becomes frail, what is its natural history, how is it managed, and what can be done to prevent it. To achieve these objectives, qualitative research should clearly articulate the conceptual and operational definition of frailty, the inclusion and exclusion criteria, and how the data will be analyzed to differentiate the voices of participants who are frail or nonfrail. Our findings signal a call to action for the use of a standardized approach to reporting how frailty is defined in abstracts and studies as proposed by Yaksic et al. [48] which will facilitate qualitative metasynthesis studies to capture the increasing volume of qualitative research and facilitate knowledge transfer and accurate reporting of scientific work in frailty that is needed to catalyze initiatives to improve healthcare.

4.9. Strengths and Limitations. This qualitative systematic review included qualitative research from multiple geographic regions and professional disciplines. A majority of articles were from European, Asian, and American countries with a lack of representation of global geographic regions such as Africa, low- and middle-income countries, and some of the most populous countries such as China, India, and Russia. There were contributions from diverse disciplines; however, in the era of globalization and team science, future research enterprises should adopt transdisciplinary collaborations to advance frailty science. While this review involved a comprehensive search of multiple databases, potentially relevant articles may have been missed, and there may be an unintended bias toward articles published in the peer-reviewed English language literature. The quality of the included articles varied, but we retained all relevant articles for a more enriched synthesis. We employed a systematic, rigorous method for data extraction, content analysis, and concept mapping for the synthesis; however, the possibility of overlooking key information or misinterpretation during these processes exists. Finally, this review concentrated on definitions of frailty in qualitative research focused on studies in community-living frail older adults; how researchers define frailty in qualitative research in other contexts such as acute care hospitals and long-term care nursing homes may differ and merits further inquiry.

\section{Conclusion}

Frailty is a compelling global public health issue that significantly impacts individuals, families, communities, and society. The anticipated increase in the incidence and prevalence of frailty and its adverse consequences underscores the need to better understand frailty. The findings from this systematic review of the qualitative literature on definitions of frailty in qualitative research on the lived experience of frailty among frail older adults indicate that frailty was conceptually defined as a multidimensional, biopsychosocial, holistic construct but was often operationally defined by older age and functional impairment. Over half of the studies were appraised to be at risk for researcher bias due to lack of clear criteria to operationalize frailty in the study methodology. This review underscores the need for clear articulation of frailty defining characteristics and objective indicators in study abstracts and methods in future qualitative research. Such transparency will facilitate cross-study comparisons and development of qualitative metasynthesis and meta-analysis studies which are necessary to expedite the development of the science base that is necessary to drive future research and guide improvements in the care for frail older adults.

\section{Data Availability}

No data were used to support this study.

\section{Conflicts of Interest}

The authors declare that there are no conflicts of interest regarding the publication of this article.

\section{Authors' Contributions}

All authors have made substantial contributions to (1) the conception and design of the study, acquisition of data, or analysis and interpretation of data, (2) drafting of the article 
or revising it critically for important intellectual content, and (3) final approval of the manuscript submitted.

\section{Acknowledgments}

The authors would like to thank Julie Barroso, Ph.D., RN, FAAN, for assistance with study design; Mona Shatell, Ph.D., RN, FAAN, and Susan Letvak, Ph.D., RN, FAAN, for review of the manuscript; Sarah Abrams, MSN, RN, and Hyewon Shin, MSN, RN, for assistance with data abstraction; and Peggy Markham, MSLS, for editorial assistance in the preparation of the manuscript.

\section{References}

[1] World Health Organization (WHO), WHO Clinical Consortium on Healthy Ageing Topic Focus: Frailty and Intrinsic Capacity, The World Health Organization, Geneva, Switzerland, 2017, https://apps.who.int/iris/bitstream/handle/ 10665/272437/WHO-FWC-ALC-17.2-eng.pdf?ua=1.

[2] M. Cesari, R. Calvani, and E. Marzetti, "Frailty in older persons," Clinics in Geriatric Medicine, vol. 33, pp. 293-303, 2017.

[3] A Clegg, J. Rogers, and J. Young, "Diagnostic test accuracy of simple instruments for identifying frailty in communitydwelling older people: a systematic review," Age and Ageing, vol. 44, no. 1, pp. 148-152, 2015.

[4] X. Chen, G. Mao, and S. X. Leng, "Frailty syndrome: an overview," Clinical Interventions in Aging, vol. 9, pp. 433-441, 2014.

[5] J. E. Morley, B. Vellas, G. A. van Kan et al., "Frailty consensus: a call to action," Journal of the Medical Directors Association, vol. 14, no. 6, pp. 392-397, 2013.

[6] R. J. Gobbens, M. A. van Assen, K. G. Luijkx, and J. M. Schols, "Testing an integral conceptual model of frailty," Journal of Advanced Nursing, vol. 68, pp. 2047-2060, 2012.

[7] R. J. Gobbens, M. A. van Assen, K. G. Luijkx, M. T. WijnenSponselee, and J. M. Schols, "The Tilburg frailty indicator: psychometric properties," Journal of the American Medical Directors Association, vol. 11, pp. 344-355, 2010.

[8] British Geriatrics Society, "Fit for frailty-a consensus best practice guidance for the care of older people living in community and outpatient settings," British Geriatrics Society, London, UK, 2017, https://www.bgs.org.uk/sites/ default/files/content/resources/files/2018-05-23/fff_full. pdf.

[9] C. Nicholson, A. L. Gordon, and A. Tinker, "Changing the way "we" view and talk about frailty," Age and Ageing, vol. 46, pp. 349-351, 2017.

[10] M. Sandelowski and J. Barroso, Handbook for Synthesizing Qualitative Research, Springer Publishing Company, Inc., New York, NY, USA, 2007.

[11] M. L. Jones, "Application of systematic review methods to qualitative research: practical issues," Journal of Advanced Nursing, vol. 48, pp. 271-278, 2004.

[12] P. Aspers and U. Corte, "What is qualitative in qualitative research," Qualitative Sociology, vol. 42, no. 2, pp. 139-160, 2019.

[13] K. Seers, "Qualitative systematic reviews: their importance for our understanding of research relevant to pain," British Journal of Pain, vol. 9, no. 1, pp. 36-40, 2015.

[14] M. J. Grant and A. Booth, "A typology of reviews: an analysis of 14 review types and associated methodologies," Health
Information \& Libraries Journal, vol. 26, no. 2, pp. 91-108, 2009.

[15] B. L. Paterson, S. E. Thorne, C. Canam, and C. Jillings, Metastudy of Qualitative Health Research, Sage Publications, Inc, Thousand Oaks, CA, USA, 2001.

[16] Z. Ebrahimi, K. Wilhelmson, C. D. Moore, and A. Jakobsson, "Frail elders' experiences with and perceptions of health," Qualitative Health Research, vol. 22, pp. 1513-1523, 2012.

[17] Z. Ebrahimi, K. Wilhelmson, K. Eklund, C. D. Moore, and A. Jakobsson, "Health despite frailty: exploring influences on frail older adults' experiences of health," Geriatric Nursing, vol. 34, pp. 289-294, 2013.

[18] A. Grenier, "The distinction between being and feeling frail: exploring emotional experiences in health and social care," Journal of Social Work Practice, vol. 20, pp. 299-313, 2006.

[19] A. Grenier and J. Hanley, "Older women and 'frailty': aged, gendered and embodied resistance," International Sociology, vol. 55, no. 2, pp. 211-228, 2007.

[20] K. Jett, "Making the connection: seeking and receiving help by elderly African Americans," Qualitative Health Research, vol. 12, no. 3, pp. 373-387, 2002.

[21] K. Jett, "The meaning of aging and the celebration of rural African-American women," Geriatric Nursing, vol. 24, no. 5, pp. 290-320, 2003.

[22] C. Nicholson, J. Meyer, M. Flatley, and C. Holman, "Living on the margin: understanding the experience of living and dying with frailty in old age," Social Science \& Medicine, vol. 75, pp. 1426-1432, 2012.

[23] C. Nicholson, J. Meyer, M. Flatley, and C. Holman, "The experience of living at home with frailty in old age: a psychosocial qualitative study," International Journal of Nursing Studies, vol. 50, pp. 1172-1179, 2013.

[24] D. Niesten, K. van Mourik, and W. van der Sanden, "The impact of frailty on oral care behavior of older people: a qualitative study," BMC Oral Health, vol. 13, no. 61, 2013.

[25] D. Niesten, K. van Mourik, and W. van der Sanden, "The impact of having natural teeth on the QoL of frail dentulous older people. A qualitative study," BMC Public Health, vol. 1, p. 839, 2012.

[26] E. J. Porter, “"Getting up from here”: frail older women's experiences after falling," Rehabilitation Nursing, vol. 24, no. 5, pp. 201-211, 1999.

[27] E. J. Porter, “An older rural widow's transition from home care to assisted living," Care Management Journal, vol. 3, no. 1, pp. 25-32, 2001.

[28] M. Puts, N. Shekary, G. Widdershoven, J. Heldens, and D. Deeg, "The meaning of frailty according to Dutch older frail and non-frail persons," Journal of Aging Studies, vol. 23, pp. 258-266, 2009.

[29] M. Puts, N. Shekary, G. Widdershoven, J. Heldens, P. Lips, and D. Deeg, "What does quality of life mean to older frail and nonfrail community-dwelling adults in The Netherlands?" Quality of Life Research, vol. 16, no. 2, pp. 263-277, 2007.

[30] Critical Appraisal Skills Programme (CASP), CASP Qualitative Studies Checklist, Oxford Centre for the Triple Value Healthcare Ltd., Oxford, UK, 2018, https://casp-uk.b-cdn.net/ wp-content/uploads/2020/10/CASP_RCT_Checklist_PDF_ Fillable_Form.pdf.

[31] J. Thomas and A. Harden, "Methods for the thematic synthesis of qualitative research in systematic reviews," BMC Medical Research Methodology, vol. 8, p. 45, 2008.

[32] H.-F. Hsieh and S. E. Shannon, "Three approaches to qualitative content analysis," Qualitative Health Research, vol. 15, no. 9, pp. 1277-1288, 2005. 
[33] I. M. Kinchkin, D. Streatfield, and D. B. Hay, "Using concept mapping to enhance the research interview," International Journal of Qualitative Methods, vol. 9, no. 1, pp. 52-68, 2010.

[34] J. Andreasen, H. Lund, M. Aadahl, R. J. J. Gobbens, and E. E. Sorensen, "Content validation of the Tilburg frailty indicator from the perspective of frail elderly. a qualitative explorative study," Archives of Gerontology and Geriatrics, vol. 61, no. 3, pp. 392-399, 2015.

[35] G. Becker, "The oldest old: autonomy in the face of frailty," Journal of Aging Studies, vol. 8, no. 1, pp. 59-76, 1994.

[36] L. Claassens, G. A. Widdershoven, S. C. Van Rhijn et al., "Perceived control in health care: a conceptual model based on experiences of frail older adults," Journal of Aging Studies, vol. 31, pp. 159-170, 2014.

[37] W. T. Donlan, "The meaning of community-based care for frail Mexican American elders," International Social Work, vol. 54, no. 3, pp. 388-403, 2011.

[38] C. Ekelund, L. Mårtensson, and K. Eklund, "Self-determination among frail older persons - a desirable goal older persons' conceptions of self-determination," Quality in Ageing and Older Adults, vol. 15, pp. 90-101, 2014.

[39] K. D. Evans, L. A. Mazzei, and M. H. Teaford, "Removing some of the gray concerning the health of frail older women," Journal of Diagnostic Medical Sonography, vol. 17, no. 4, pp. 203-211, 2001.

[40] I. Hammar, S. Dahlin-Ivanoff, K. Wilhelmson, and K. Eklund, "Shifting between self-governing and being governed: a qualitative study of older persons' self-determination," BMC Geriatrics, vol. 14, no. 126, pp. 1-8, 2014.

[41] S. R. Kaufman, "The social construction of frailty: an anthropological perspective," Journal of Aging Studies, vol. 8, no. 1, pp. 45-58, 1994.

[42] M. Kuo, C. Chen, and C. Jeng, "Development of frailty indicators for the community-dwelling older adults," Journal of Nursing Research, vol. 20, no. 4, pp. 261-271, 2012.

[43] S. Z. Moss, M. S. Moss, J. E. Kilbride, and R. L. Rubinstein, "Frail men's perspectives on food and eating," Journal of Aging Studies, vol. 21, no. 4, pp. 314-324, 2007.

[44] P. O'Connor, "Salient themes in the life review of a sample of frail elderly respondents in London," Gerontologist, vol. 34, pp. 224-230, 1994.

[45] N. L. Schoenborn, S. E. Van Pilsum Rasmussen, Q. Xue et al., "Older adults' perceptions and informational needs regarding frailty," BMC Geriatrics, vol. 18, p. 46, 2018.

[46] C. Tocchi, "Frailty in older adults: an evolutionary concept analysis," Research in Theory for Nursing Practice: An International Journal, vol. 29, no. 1, pp. 66-84, 2015.

[47] S. Frietag and S. Schmidt, "Psychosocial correlates of frailty in older adults," Geriatrics, vol. 1, no. 4, p. 26, 2016.

[48] E. Yaksic, V. Lecky, S. Sharnprapai et al., "Defining frailty in research abstracts: a systematic review and recommendations for standardization," Journal of Frailty and Aging, vol. 8, no. 2, pp. 67-71, 2019.

[49] U. Junius-Walker, G. Onder, D. Soleymani et al., "The essence of frailty: a systematic review and qualitative synthesis on frailty concepts and definitions," European Journal of Internal Medicine, vol. 56, pp. 3-10, 2018.

[50] D. Sezgin, M. O’Donovan, N. Cornally, A. Liew, and R. O'Caoimh, "Defining frailty for healthcare practice and research: a qualitative systematic review with thematic analysis," International Journal of Nursing Studies, vol. 92, pp. 16-26, 2019.

[51] J. W. Faller, D. N. Pereira, S. de Souza, F. K. Nampo, F. S. Orlandi, and S. Matumoto, "Instruments for the detection of frailty syndrome in older adults: a systematic review," PLoS One, vol. 14, no. 4, Article ID e0216166, 2019.

[52] S. E. Espinoza, M. Quiben, and H. P. Hazuda, "Distinguishing comorbidity, disability, and frailty," Current Geriatrics Reports, vol. 7, no. 4, pp. 201-209, 2018.

[53] L. P. Fried, L. Ferrucci, J. Darer, J. D. Williamson, and G. Anderson, "Untangling the concepts of disability, frailty, and comorbidity: implications for improved targeting and care," Journals of Gerontology. Series A, Biological Sciences and Medical Sciences, vol. 59, no. 3, pp. 255-563, 2004.

[54] K. Bandeen-Roche, C. L. Seplaki, J. Huang et al., "Frailty in older adults: a nationally representative profile in the United States," Journals of Gerontology Series A: Biological Sciences \& Medical Sciences, vol. 70, pp. 1427-1434, 2015.

[55] L. Lafortune, S. Martin, S. Kelly et al., "Behavioural risk factors in mid-life associated with successful ageing, disability, dementia and frailty in later life: a rapid systematic review," PLoS One, vol. 11, no. 2, Article ID e0144405, 2016.

[56] P. Chatterjee, "Understanding frailty: the science and beyond," in Health and Wellbeing in Late LifeSpringer, Singapore, 2019.

[57] L. Rodríguez-Mañas, C. Féart, G. Mann et al., "Searching for an operational definition of frailty: a Delphi method based consensus statement. The Frailty Operative Definition-Consensus Conference Project," Journals of Gerontology Series A: Biological Sciences and Medical Sciences, vol. 68, pp. 62-67, 2013.

[58] S. Bunt, N. Steverink, J. Olthof, C. P. van der Schans, and J. S. M. Hobblen, "Social frailty in older adults: a scoping review," European Journal of Ageing, vol. 14, no. 3, pp. 323-334, 2017.

[59] A. M. Chamberlain, J. L. St Sauver, D. J. Jacobson et al., "Social and behavioural factors associated with frailty trajectories in a population-based cohort of older adults," BMJ Open, vol. 6, no. 5, Article ID e011410, 2016.

[60] S. H. van Oostrom, A. D. L. van der, M. L. Rietman et al., “A four-domain approach of frailty explored in the Doetinchem cohort study," BMC Geriatrics, vol. 17, no. 1, p. 196, 2017.

[61] M. Carnevelli and M. Cesari, "Cognitive frailty: what is still missing?" Journal of Nutrition, Health \& Aging, vol. 19, no. 3, pp. 273-275, 2015.

[62] M. K. Andrew, "Frailty and social vulnerability," Frailty in Aging, vol. 41, pp. 186-195, 2015.

[63] S. E. Kirby, P. G. Coleman, and D. Daley, "Spirituality and well-being in frail and nonfrail older adults," Journals of Gerontology B Psychological Science Social Science, vol. 59, no. 3, pp. P123-P129, 2004.

[64] D. A. Lekan, E. Hoover, and S. Abrams, "Perceptions of frailty among African American men and women," Journal of Psychosocial Nursing and Mental Health Services, vol. 56, no. 7, pp. 20-29, 2018.

[65] K. Rockwood, X. Song, C. MacKnight et al., "A global clinical measure for fitness and frailty in elderly people," CMAJ, vol. 173, no. 5, pp. 489-495, 2005.

[66] S. D. Searle, A. Mitnitski, E. A. Gahbauer, T. M. Gill, and K. Rockwood, "A standard procedure for creating a frailty index," BMC Geriatrics, vol. 8, p. 24, 2008.

[67] S. Mueller-Schotte, N. P. Zuithoff, Y. T. van der Schouw, M. J. Schuurmans, and N. Bleijenberg, "Trajectories of limitations in instrumental activities of daily living in frail older adults with vison, hearing, or dual sensory loss," Journals of Gerontology A Biological Science Medical Science, vol. 74, no. 6, pp. 936-942, 2019. 
[68] S. B. Gee, G. Cheung, U. Bergler, and H. Jamieson, ““There’s more to frail than that": older New Zealanders and health professionals talk about frailty," Journal of Aging Research, vol. 2019, Article ID 2573239, 2019.

[69] A. A. Hayajneh, "The psychometric properties of the Arabic version of the Tilburg frailty indicator," Global Journal of Health Science, vol. 11, no. 9, pp. 123-133, 2019.

[70] S. F. Chang and G. M. Wen, "Association of frail index and quality of life among community-dwelling older adults," Journal of Clinical Nursing, vol. 25, pp. 2305-2316, 2016.

[71] B. G. Link and J. C. Phelan, "Conceptualizing stigma," Annual Review of Sociology, vol. 27, pp. 363-385, 2001.

[72] Age-UK, Don't Call Me Frail, 2015, https://www.ageuk.org. uk/latest-press/archive/using-the-word-frailty-could-stopolder-people-accessing-vital-services/. 